\title{
Environmental factors affecting roost use of shorebirds in the southem Kanghwa Island, Republic of Korea
}

\author{
Kwan Mok Kim · Young Min Moon · Jeong Chil Yoo
}

Department of Biology, Kyung Hee University

\section{강화도 남단에 도래하는 도요새들의 해안 내륙 휴식지 이용과 이들의 이용에 영향을 미치는 환경요인들}

\author{
김관목 · 문영민 · 유정칠+
}

경희대학교 생물학과

\begin{abstract}
There are some factors affecting the shorebirds in selecting a coastal inland roost site where they have to stay during the high tide when the entire intertidal zone is covered with water. We investigated eight species (Eastern Curlews Numenius madagascariensis, Green Shanks Tringa nebularia, Bar-tailed Godwits Limosa lapponica, Grey Plovers Pluvialis squatarola, Dunlins Calidris alpine, Whimbrels Numenius phaeopus, Eurasian Curlews Numenius arquata and Terek Sandpipers Xenus cinereus) to identify the spatial and temporal variability in coastal inland roost use in the area and the factors influencing the use. We considered the area and length of the standing water in the roost site, temperature, wind speed, the time of migration and the intensity of disturbance. As a result, number of individuals and type of species using the roost site varied across spatial and temporal scales. And the factors affecting the roost use was species-specific. The roost site of the study area was a closed shrimp farm however, it has been converted to a Salicornia herbacea, a salt marsh plant, farm recently. In a situation where coastal inland roost site is needed, we hereby describe a resolution for the juxtaposition of shorebirds and farming.
\end{abstract}

Keywords : coastal inland roost, conservation, EAAF, Kanghwa Island, roost site shorebirds, stopover site

요 약

도요·물떼새들은 만조시에 해안 내륙 휴식지에서 휴식을 취하는데, 휴식지를 선택할 때 여러 가지 요소들을 고려한다. 우리는 도요·물떼새 8종(알락꼬리마도요 Numenius madagascariensis, 청다리도요 Tringa nebularia, 큰뒷부리도요 Limosa lapponica, 개꿩 Pluvialis squatarola, 민물도요 Calidris alpine, 중부리도요 Numenius phaeopus, 마도요 Numenius arquata, 뒷부리도요 Xenus cinereus)을 대상으로 휴식지의 시공간적 이용과 그 이용에 영향을 미치는 요인들을 분석하였다. 휴 식지 내 고인 물의 면적과 길이, 기온, 풍속, 종별로 이동시기, 방해정도를 변수로 고려하였다. 시공간적으로, 이용하 는 종이 달랐으며 개체수 또한 변동을 거듭하였다. 그리고 도요·물떼새의 휴식지 이용에 영향을 미치는 요인은 종-특 이적이었다. 연구지역의 휴식지는 폐장한 새우양식장이었으나 조사 기간 중 염생습지에서 자라는 함초 Salicornia herbacea 농장으로 전환하였다. 휴식지가 필요한 상황에서, 도요·물떼새들의 생태를 기초로 해서 기존 휴식지를 관리 할 것을 권한다. 더불어, 여름철 가뭄에는 양식장의 수문을 열어주어 도요·물떼새들이 물을 이용해 체온관리를 할 수 있게 해주고, 만조시 도요·물떼새들이 양식장 안으로 날아 들어올 수 있도록 새들이 휴식지를 찾기 시작하는 만조 전 네 시간부터는 농장 작업을 안 할 것을 권한다.

핵심용어 : 도요새, 휴식지, 강화도, 보전, 해안 내륙 휴식지, 중간 기착지, 동아시아대양주 이동경로

\section{Introduction}

Migratory shorebirds forage in the mudflat and from the rising tide they become forced to wade to the near coastline and roost in the intertidal habitats (Rogers et al. 2006a). However, when it becomes spring tide, or the time when the mudflat and the coast is completely covered with water, shorebirds fly inland to nearest roost

+ Corresponding author : jcyoo@khu.ac.kr 
sites for example, rice paddies, salt pans, salt marshes, shrimp farms etc. and many congregated shorebirds are found in coastal inland roost sites behind the intertidal zone (Kim 2003a, Rogers et al. 2006a). Similar to the intertidal roost site shorebird species, Dunlins Calidris alpina, Black-tailed Godwits Limosa limosa (pers.obs.), (Common) Green Shanks Tringa nebularia, are observed to forage in the flooded rice paddy to refuel its' energy (Kim 2003b) and some species were found to forage in the rice paddy although the mudflat was available (pers.obs.) and if the coastal inland roost site is close to the foraging area the shorebirds could minimize energy expenditure (Piersma et al. 1993). Moreover, the local shorebird population could be affected by a human disturbance in the roost site (Pfister et al. 1992). From these cases the coastal inland roost site is imperative to the shorebirds. However, with ongoing developments in the coastal habitats (Mackinnon et al. 2012a), the rice paddies, salt pans, fish farms located in the coastal areas have been changed for other purposes and have negatively affected the shorebird population (Mackinnon et al. 2012b).

There has been active research on the types of roost sites the shorebirds use and the environmental factors related to the incidence (Colwell and Dodd 1997, Danufsky and Colwell 2003, Kim 2003a, Peters and Otis 2007, Rogers et al. 2006a). According to the available information on roosting ecology of shorebirds, they consider the energetic costs (Rogers et al. 2006b), predator risk (Dekker 1998, Dekker and Ydenberg 2004), the area flooded (Kelsy and Hassall 1989), the wind speed (Peters and Otis 2007), temperature (Rogers et al. 2006 b) etc. when selecting a roost site. It's also suggested that human disturbance and activities could affect the shorebirds in determining the roost site (Burton et al. 1996). Furthermore there has been a work on a spatial and temporal scales of roost site selection (Peters and Otis 2007). However, most of the research was conducted in wintering sites or breeding sites therefore, we are lacking information on the stopover sites where shorebirds replenish in the middle of migration (Mackinnon et al. 2012c). Furthermore, the shorebirds' condition in the staging sites affects the survival of the individual in the breeding site (Skagen 2006, Morrison and Hobson 2004) which conveys the importance and the need for a research in the stopover site.

Here we examine the southern Kanghwa Island, Republic of Korea, a staging site in the East coast of the
Yellow Sea on the East Asian-Australasian Flyway (EAAF) to 1) examine the daily and annual use of coastal inland roost sites, 2) determine how the anthropogenic factor affects the use, 3) identify which environmental factors such as temperature and the wind speed affects the shorebirds' use and 4) suggest a management plan for the site.

\section{Methods}

\subsection{Study Area}

Southern part of Kanghwa Island (Latitude:37.58, Longitude:126.40; Fig. 1), Republic of Korea is located in one of the 16 key areas of shorebirds in the EAAF (Mackinnon et al. 2012d) and designated as a Key Area among Important Bird Area (IBA)s, IBA number 5 (Mackinnon et al. 2012e), having high biodiversity of shorebirds (Mackinnon et al. 2012e). And the mudflat in the southern part of Kanghwa Island is also designated as a natural monument (6 July, 2000; no.419) by the Cultural Heritage Administration of the Republic of Korea and evaluated as grade $\mathrm{V}$ according to Lee et al. 2004 therefore, provides a safe and high quality foraging area. However, many hinterlands of tidal flat areas are being developed following road constructions, restaurants, motels in Republic of Korea (Moores 2007) and so does the

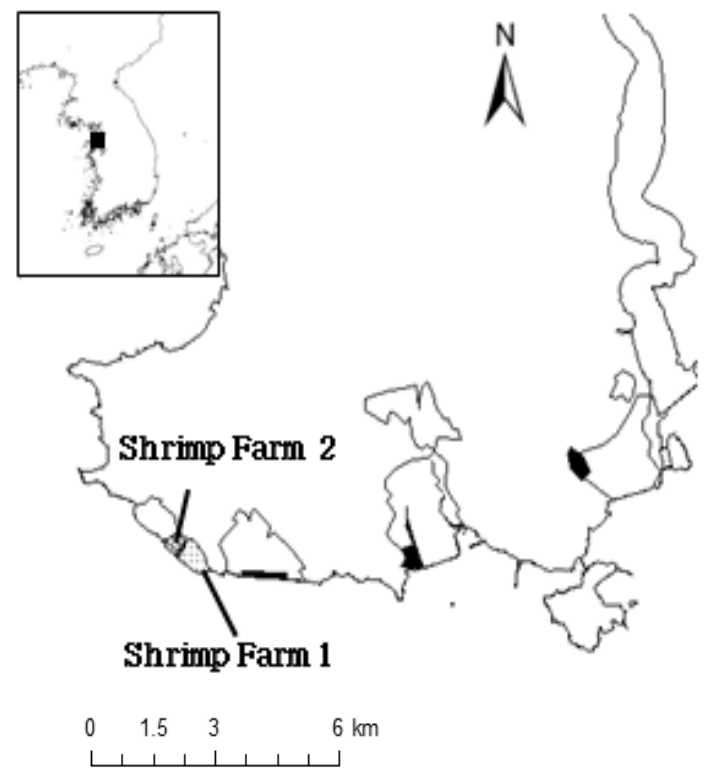

Fig. 1. Study area of the Shrimp Farms in the southern part of Kanghwa Island, Republic of Korea. The total shorebird census of the southern Kanghwa Island were carried out along the coastline. 
southern Kanghwa Island constructing motels, restaurants, and eco-tourism trails (Nadeulgil) along the coastline disrupting the shorebirds (pers.obs.).

Southern part of Kanghwa Island is consisted of a mountain, few forests, rice paddies (partly closed), closed shrimp farms, reservoir and a beech. Roost sites shorebirds could use are the rice paddies, closed Shrimp Farm 1 and 2, which are attached to each other locating just behind the mudflat divided by a dyke (Fig. 1). Reservoir cannot be used as a roost site because people fish there and it is near to houses and a road. However, compared to year 2002 (Kim 2003a) rice fields are only partially running and as a consequence most of the area are unflooded being unattractive to the shorebirds (Moores 2006). Shrimp Farm 1 is surrounded by a dyke and ground cover is homogeneous filled with mudflats. Shrimp Farm 2 delineated into three sectors with a dyke the ground is also filled with mudflats. The two attached Shrimp Farms are currently the last available coastal inland roost sites. However, the Shrimp Farm 2 is too narrow to accommodate all the shorebirds and most of all the least area has slopes therefore only available for a specific species. What's worse the new owner of the Shrimp Farm 1 has converted the empty farm into a Salicornia herbacea, a salt marsh plant prescribed in traditional medicines for a long time (Park et al. 2009), farm. Here we use the term Shrimp Farm through out the literature instead of $S$. herabacea Farm. Since then there has been consistent changes in the Shrimp Farm 1 draining off water in early April 2012, sowing as the water level decreases, occasional entrance inside the roost till September 2012 and harvest since the early October 2012. An alternate roost site exists in the Yeongjong Island across the mudflat 10km far (Kim and Yoo 2004, pers.obs) which is an empty dredged soil reclamation area however, as there were no environmental changes in the empty area affecting the shorebirds (per.obs.) we did not consider this site into account.

\subsection{Survey Methods}

We conducted 26 bird surveys from September 2011 to November 2012. On the main migratory seasons (March, April, May, July, August, September, October, November) we surveyed twice a month every other week and once in the non-migratory season. After the bird census was conducted near the coastline, we have conducted a separate roost site survey in the Shrimp Farm1, 2 and rice paddy before half an hour to high tide when the population was stable; rice paddy not presented in this article. In order to be precise of the shorebird counts, census was conducted on the day when the high tide was over $780 \mathrm{~cm}$, when the high tide covered all the intertidal habitats.

\subsection{Roost Site and Environmental Variables}

The wind speed and temperature data was obtained from the nearest weather station $3.5 \mathrm{~km}$ away from the study area (downloaded from the Korea Meteorological Administration) and used data matching with the census date. The mean value of the ten minutes-interval data $(\mathrm{N}=13)$ two hours prior to the high tide (Appendix) was used. Disturbance variable was based on the farming schedule obtained from the owner of the $S$. herbacea Farm. We divided the variable into three stages: before any measures were taken, after sowing process and the harvest period and have given a dummy number respectively, 0, 1 and 2. And to see the relationship between the roost use and migration cycles of the shorebirds, we applied the Julian date (Peters and Otis 2007) and named the variable Time of Year.

The area of the standing water affects the shorebird distribution (Connor and McCoy 1979) and the species congregate around the line of the water (Danufsky and Colwell 2003) as the depth is suitable for the shorebirds therefore, we measured the area of the (standing) water and the circumference of the water. Here we use, the term 'length of water' throughout the passage to state the circumference of the water. Based on ground truth data, we used the Landsat TM images to calculate the values of the variables (Fig. 2). We used nine Landsat images (3 September 2011, 22 November 2011, 13 March 2012, 30 April 2012, 1 June 2012, 5 September 2012, 7 October 2012, 23 October 2012, 24 November 2012) available from the U.S. Geological Survey and concerning with the technical problems with the Scan Line Corrector of Landsat 7 (U.S Geological Survey, http://calval.cr.usgs.gov/ LDGST.php), prior to analysis we filled the gaps with the latest images with similar environmental status. Exclusive of the nine data extracted from the satellite images, to calculate the 17 other values matching the survey data, we used a simple linear regression equation to predict the values from the nine satellite images (Appendix). Shorebirds roost in a point where they feel safe, especially in the middle (Stillman et al. 2005), likewise roosted $100 \mathrm{~m}$ away from the dyke (pers.obs.), so we have set up a 
(a)

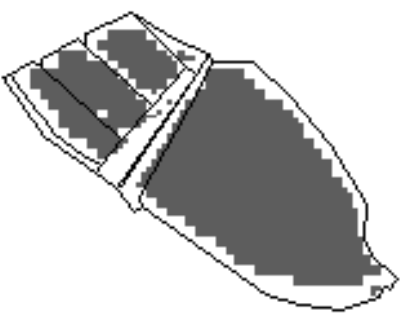

(c)

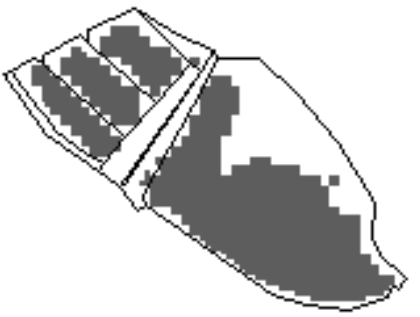

(e)

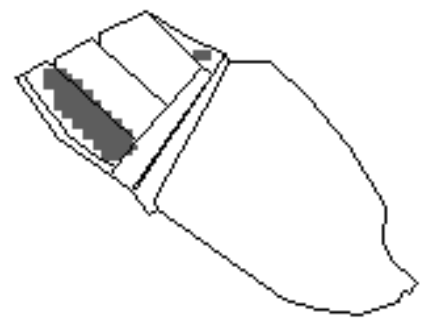

(g)

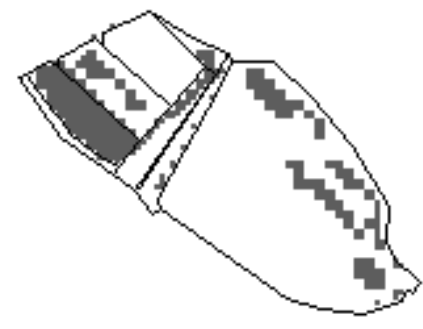

(i)

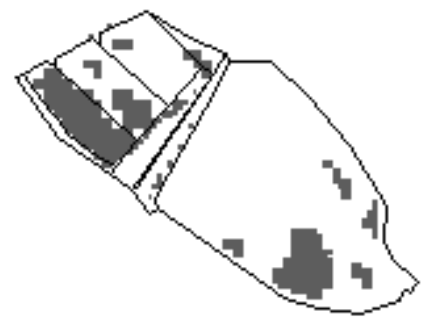

(b)

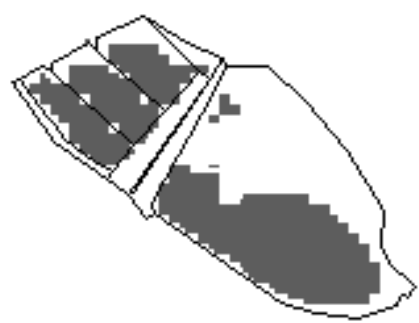

(d)

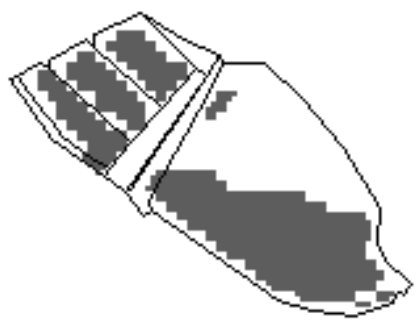

(f)

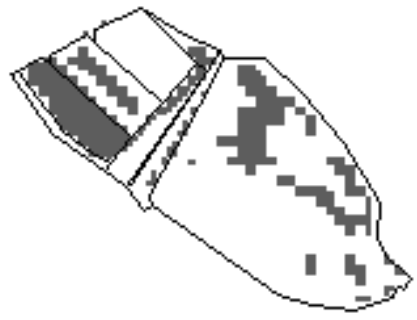

(h)

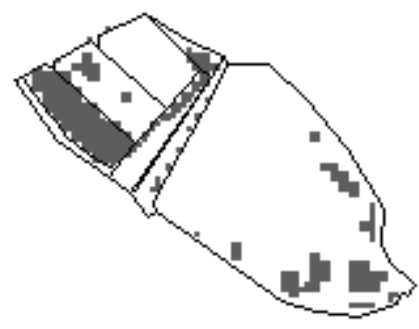

Shrimp farm stage

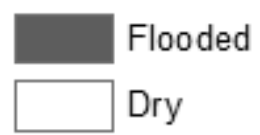

$0 \quad 250 \quad 500 \quad 1,000 \mathrm{M}$

Fig. 2. Change of the flooded area based on Landsat images:(a) 3 September 2011, (b) 22 November 2011, (c) 13 March 2012, (d) 30 April 2012, (e) 1 June 2012, (f) 5 September 2012, (g) 7 October 2012, (h) 23 October 2012, (i) 24 November 2012. 
Table 1. Spearman correlation coefficients for environmental factors measured during the 26 surveys in the southern Kanghwa Island, Republic of Korea. Correlations significant at $\mathrm{P}<0.05$ are displayed in bold.

\begin{tabular}{|c|c|c|c|c|c|c|}
\hline & Water Area & Water Length & Water Area/Length & Temperature & Wind Speed & Time of Year \\
\hline Water length & 0.15 & & & & & \\
\hline $\begin{array}{c}\text { Water } \\
\text { Area/Length }\end{array}$ & 0.81 & -0.30 & & & & \\
\hline Temperature & -0.29 & -0.22 & -0.22 & & & \\
\hline Wind Speed & -0.25 & -0.12 & -0.14 & -0.32 & & \\
\hline Time of Year & -0.22 & -0.26 & -0.09 & 0.01 & 0.12 & \\
\hline Disturbance & -0.84 & -0.13 & -0.63 & 0.26 & 0.23 & 0.14 \\
\hline
\end{tabular}

$100 \mathrm{~m}$ bufferzone from the edge and only used the data inside the zone. The Shrimp Farm 2 was rarely used from shorebirds and little environmental changed occurred during the survey therefore was not included in the analysis. EXCEL was used for calculation of the temperature and the windspeed and ERDAS IMAGINE 9.2 was used for Landsat Image analysis and ARC GIS 10.0 for spatial analysis.

\subsection{Statistical Analysis}

Only the species that have used the roost site more than 50 individuals and used more than 11 incidents has been analysed; the Eastern Curlew Numenius madagascariensis, the Green Shank, the Bar-tailed Godwit Limosa lapponica, the Grey Plover Pluvialis squatarola, the Dunlin, the Whimbrel Numenius phaeopus, the Terek Sandpiper Xenus cinereus and the Eurasian Curlew Numenius arquata (Fig. 3). To calculate the number of times use of each species (Shrimp Farm 1 and 2 during the 26 surveys), based on the incidence we used the total number of visits. And to calculate the annual (during 26 surveys) proportion use we divided the value to the total times the species was observed in the southern Kanghwa Island (Table 2). When there were no population during the census, the species value was regarded as null and was not used for analysis. To examine the daily proportion use of the Shrimp Farm we used the total counts of each shorebird species from the 11 sites and the total daily population (Fig. 3).

Table 2. Shorebird species and number of total observations in the Shrimp Farm during the 26 surveys (from September 2011-November 2012) in the southern Kanghwa Island. Also the annual roost use (during 26 surveys) of Shrimp Farm 1 and 2 are presented.

\begin{tabular}{|c|c|c|c|c|c|c|}
\hline \multirow{3}{*}{$\begin{array}{l}\text { Common Name } \\
\text { Eastern Curlew }\end{array}$} & \multirow{3}{*}{$\begin{array}{l}\text { Scientific Name } \\
\text { Numenius madagascariensis }\end{array}$} & \multirow{3}{*}{$\begin{array}{c}\begin{array}{c}\text { Number of } \\
\text { observations }\end{array} \\
3625\end{array}$} & \multicolumn{4}{|c|}{ 1) Proportion Use } \\
\hline & & & \multicolumn{2}{|c|}{ Shrimp Farm 1} & \multicolumn{2}{|c|}{ Shrimp Farm 2} \\
\hline & & & 0.60 & $(12 / 20)^{2)}$ & 0.10 & $(2 / 20)$ \\
\hline Green Shank & Tringa nebularia & 2089 & 0.41 & $(7 / 17)$ & 0.47 & $(8 / 17)$ \\
\hline Bar-tailed Godwit & Limosa lapponica & 1030 & 0.40 & $(6 / 15)$ & 0.00 & $(0 / 15)$ \\
\hline Great Knot & Calidris tenuirostris & 853 & 0.56 & $(5 / 9)$ & 0.11 & $(1 / 9)$ \\
\hline Grey Plover & Pluvialis squatarola & 806 & 0.40 & $(8 / 20)$ & 0.05 & $(1 / 20)$ \\
\hline Dunlin & Calidris alpina & 768 & 0.20 & $(4 / 20)$ & 0.00 & $(0 / 20)$ \\
\hline Whimbrel & Numenius phaeopus & 417 & 0.45 & $(5 / 11)$ & 0.09 & $(1 / 11)$ \\
\hline Black-tailed Godwit & Limosa limosa & 285 & 0.60 & $(3 / 5)$ & 0.00 & $(0 / 5)$ \\
\hline Terek Sandpiper & Xenus cinereus & 183 & 0.15 & $(2 / 13)$ & 0.08 & $(1 / 13)$ \\
\hline Red-necked Stint & Calidris ruficollis & 120 & 0.50 & $(1 / 2)$ & 0.00 & $(0 / 2)$ \\
\hline Eurasian Curlew & Numenius arquata & 52 & 0.31 & $(5 / 16)$ & 0.06 & $(1 / 16)$ \\
\hline Eurasian Oystercatcher & Haematopus ostralegus & 4 & 0.17 & $(3 / 18)$ & 0.06 & $(1 / 18)$ \\
\hline Wood Sandpiper & Tringa glareola & 1 & 0.20 & $(1 / 5)$ & 0.00 & $(0 / 5)$ \\
\hline
\end{tabular}

1) Annual proportion use based on the incidence of the shorebird species using the roost site out of 26 surveys.

2) The number in the parenthesis: number of incidence in the roost site/number of observations in the southern Kanghwa Island during the 26 surveys. 

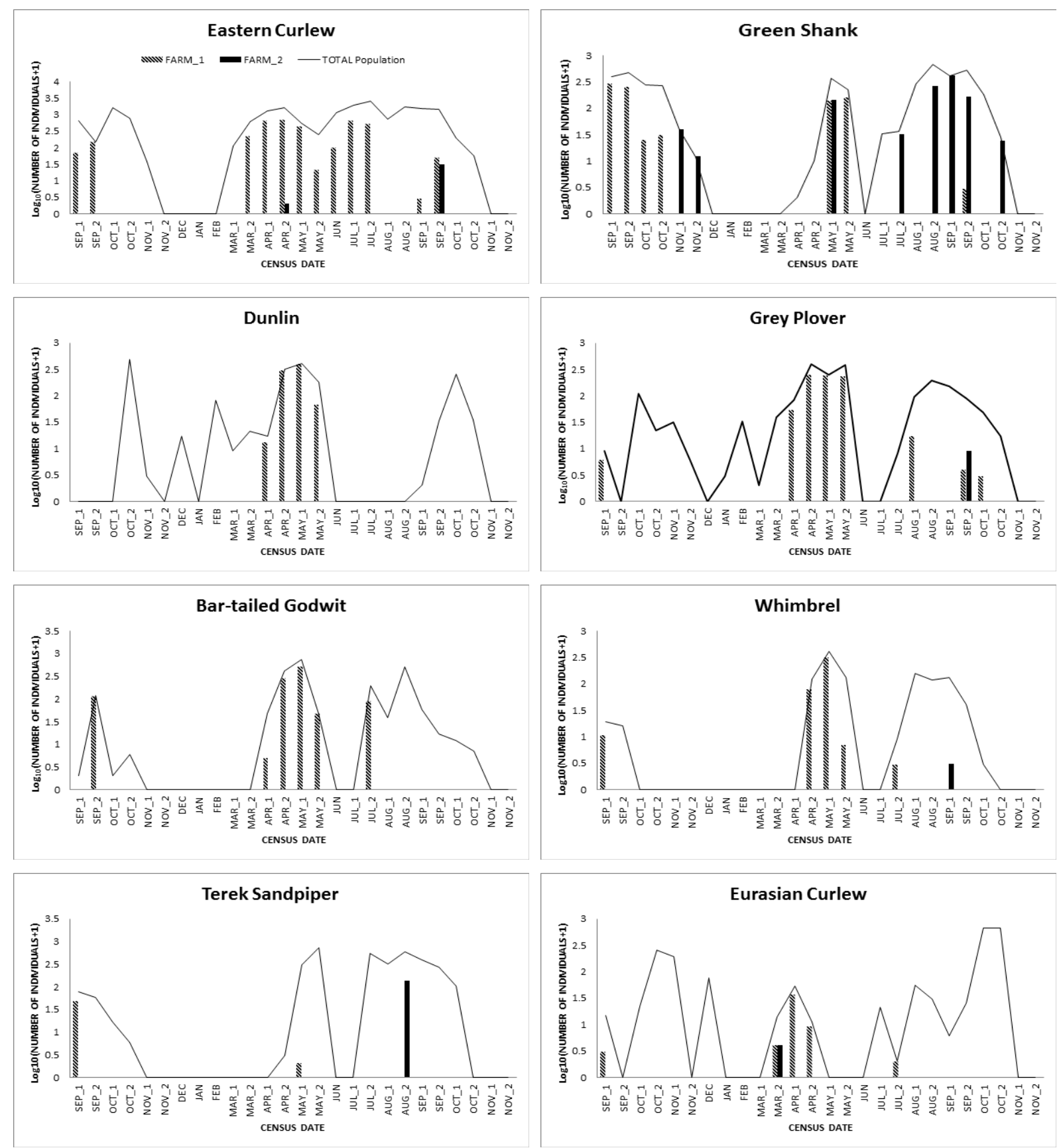

Fig. 3. Daily total number of individuals observed in the southern Kanghwa Island and the number of individuals using the Shrimp Farm 1 and 2 are presented for the eight shorebird species from early September 2011 to late November 2012; marked _ 1 for the first survey and 2 for the second survey. The number of individuals are log transformed.(Spring:Mar.,Apr.,May, Summer: Jun.,Jul.,Aug., Fall: Sep.,Oct.,Nov.)

We used a Generalized Linear Model (GLM, logit link function and quasibinomial error structure to account for overdispersion) to examine the relationship between the number of individuals out of the total population (daily) using the Shrimp Farm 1, the response variable, and the changing environmental variables, the explanatory variables (Table 2). Previous studies using logistic regression method used the presence/absence as the response variable
(Colwell and Dodd 1997, Danufsky and Colwell 2003) therefore couldn't define the cause of the increase or decrease of the number of individuals but only were informed of what variables are related to its presence/absence. We wanted to look for the variables which could explain the change in the number of individuals' use of the shorebirds therefore, instead of binary numbers we used the actual numbers into account 
(Crawley 2013). We applied log transformation to the time of year (Julian Date), area of water, circumference of the water and to prevent multicollinearity among variables, we tested the Spearman Correlation (Table 1) and eliminated the area of water variable for a reason of high correlation between another variable and instead inserted the area/length of the water variable which includes both area and the circumference values and had less correlation effects (Table 3).The area/length variable explains the shape and the distribution of the standing water regarding the flooded area as a circle. Higher value means the standing water is close to one whole area and lower value means it has an irregular shape. Furthermore, to prevent multicollinearity we checked the Variance Inflation Factor (VIF) when selecting explanatory variables in the model and only used the variables smaller than 10 (Danufsky and Colwell 2003). We used statistical program R (R Core Team 2012) for GLM analysis and considered results significant when $P$ values were smaller than 0.05 .

Table 3. Analysis on the change in the proportion using the Shrimp Farm 1 in relation to the environmental factors. (GLM analysis based on Quasi binomial error structure and logit link function)

\begin{tabular}{|c|c|c|c|c|c|}
\hline Species & Variables & $\mathrm{N}$ & Beta coefficient & SE & $P$ \\
\hline \multirow[t]{5}{*}{ Eastern Curlew } & Area/Length of water & 20 & 0.32 & 0.30 & 0.29 \\
\hline & Time of year & & -2.51 & 0.80 & $<0.01$ \\
\hline & Disturbance & & 0.68 & 1.12 & 0.55 \\
\hline & Temperature & & 0.09 & 0.09 & 0.32 \\
\hline & Wind Speed & & 0.19 & 0.37 & 0.63 \\
\hline \multirow[t]{4}{*}{ Green Shank } & Area/Length of water & 17 & 1.52 & 0.23 & $<0.001$ \\
\hline & Time of year & & -3.89 & 0.72 & $<0.001$ \\
\hline & Temperature & & 0.06 & 0.06 & 0.34 \\
\hline & Wind Speed & & 0.06 & 0.30 & 0.84 \\
\hline \multirow[t]{3}{*}{ Bar-tailed Godwit } & Time of year & 15 & -4.39 & 1.33 & $<0.01$ \\
\hline & Disturbance & & -5.31 & 2.44 & 0.05 \\
\hline & Wind Speed & & -0.28 & 0.68 & 0.69 \\
\hline \multirow[t]{5}{*}{ Grey Plover } & Area/Length of water & 20 & -1.86 & 0.56 & $<0.01$ \\
\hline & Time of year & & -3.59 & 1.18 & $<0.01$ \\
\hline & Disturbance & & 3.31 & 1.16 & $<0.05$ \\
\hline & Temperature & & 0.19 & 0.06 & $<0.01$ \\
\hline & Wind Speed & & 1.02 & 0.44 & $<0.05$ \\
\hline \multirow[t]{4}{*}{ Dunlin } & Area/Length of water & 14 & -0.84 & 2.32 & 0.73 \\
\hline & Time of year & & -3.13 & 2.23 & 0.19 \\
\hline & Temperature & & 0.42 & 0.26 & 0.13 \\
\hline & Wind Speed & & 2.03 & 1.47 & 0.19 \\
\hline \multirow[t]{3}{*}{ Whimbrel } & Area/Length of water & 11 & 2.27 & 11.49 & 0.85 \\
\hline & Time of year & & -0.15 & 47.22 & 1.00 \\
\hline & Wind Speed & & 2.17 & 3.49 & 0.55 \\
\hline \multirow[t]{3}{*}{ Terek Sandpiper } & Disturbance & 13 & -7.22 & 2.71 & $<0.05$ \\
\hline & Temperature & & -0.63 & 4.50 & 0.89 \\
\hline & Wind Speed & & -2.83 & 27.37 & 0.92 \\
\hline \multirow[t]{4}{*}{ Eurasian Curlew } & Area/Length of water & 16 & 1.09 & 1.50 & 0.48 \\
\hline & Time of year & & -6.03 & 1.78 & $<0.01$ \\
\hline & Disturbance & & 3.01 & 8.02 & 0.71 \\
\hline & Wind Speed & & -0.38 & 3.45 & 0.91 \\
\hline
\end{tabular}




\section{Results}

\subsection{Shorebird observation and the annual use of the Shrimp Farms}

During the 26 surveys, 13 shorebird species were observed using the Shrimp Farm 1 and 2. 3,625 individuals of Eastern Curlews, 2,089 individuals of Green Shanks, 1,030 individuals of Bar-tailed Godwits, 853 Great Knots and 2,636 other 9 species were observed (sum of 26 surveys) (Table 2, Appendix). The annual use of the roost site fluctuated by species (Table 2 and Fig. 3). The Eastern Curlew used the Shrimp Farm 1 as much as the proportion of 0.6 during the 26 surveys and Terek Sandpipers used only twice out of 13 visits $(0.15)$ in the southern Kanghwa Island. However, compared to Shrimp Farm 1, most of species rarely used the Shrimp Farm 2. Bar-tailed Godwits, Dunlins, Black-tailed Godwits, Red-necked Stints and Wood Sandpipers did not use the Shrimp Farm 2 at all. However, Green Shanks ,exceptionally, used the Shrimp Farm 2, eight times out of 17 visits (0.47) in the southern Kanghwa Island. Seasonally, the Shrimp Farm 1 was used highly in the Spring (March to May) 2012 (except for the Terek Sandpiper) and in the Fall (September to November) of 2011 except for the Dunlins (Fig. 3). In the Fall of 2012 however, number of individuals using the Shrimp Farm 1 varied among species. Eastern Curlews, Green Shanks and Grey Plovers roosted in the Shrimp Farm 1, however Bar-tailed Godwits, Dunlins, Whimbrels, Terek Sandpipers and Eurasian Curlews did not use the site at all. Shrimp Farm 2 wasn't used throughout the survey until the Fall of 2012 with some exceptions of Eastern Curlews, Green Shanks and Eurasian Curlews. However, the Eastern Curlew and the Eurasian Curlew used only once before the Fall 2012. In a whole, from September 2011 to July 2012 Shrimp Farm 1 was highly used and after July 2012 Shrimp Farm 2 was used by some of the species (Fig. 3).

\subsection{Change in the daily number of individuals using the roost site and the environmental factors}

Except for the Dunlin and the Whimbrel, there were significant variables that explained the change in the number of individuals roosting on Shrimp Farm 1 (Table 3). The proportion using the Shrimp Farm 1 correlated negatively with the time of year $(\mathrm{N}=20, P<0.01$, Table 3)in Eastern Curlews. A higher proportion used the Shrimp Farm 1 in the earlier times based on the Julian date. The proportion of roosting Green Shanks had a positive correlation with the area/length of water variable $(\mathrm{N}=17, P<0.001$, Table 3$)$ and a higher proportion were found in Spring $(P<0.001$, Table 3). Bar-tailed Godwits $(\mathrm{N}=15, P<0.01)$ and Eurasian Curlews $(\mathrm{N}=16, P<0.01)$ also highly used the Shrimp Farm 1 in the Spring. The proportion using the roost in Grey Plovers had significant correlation with every variables (Table 3 ). The proportion negatively correlated with the area/length of water $(\mathrm{N}=20$, $P<0.01)$ and the time of year $(P<0.01)$, positively with the disturbance $(P<0.05)$, temperature $(P<0.01)$ and wind speed $(P<0.05)$. The proportion using the roost site in Terek Sandpipers had a negative correlation with the disturbance variable $(\mathrm{N}=13, \quad P<0.05)$ having lower proportion of use in higher disturbance situations.

\section{Discussion}

\subsection{Annual use of the Shrimp Farms}

There had been a fluctuation in the proportion of shorebirds using the roost and a fluctuation in the migration cycle among species (Fig. 3). And, there have been periods when there were no individuals observed (Fig. 3). During the 26 surveys the annual use of the Shrimp Farm 1 was less than or equal to 0.6 and less than or equal to 0.47 in the Shrimp Farm 2 (Table 2) which coincides with other research results which has seen a fluctuation in number of shorebirds using the roost site (Peters and Otis 2007). The shorebirds in Kanghwa Island used the dredged soil reclamation area, another roost site in the Yeongjong Island (pers.obs.). Therefore, shorebirds in the southern Kanghwa Island are currently roosting on Shrimp Farms and a dredged soil reclamation area. However, with previous studies this study has proved that there is a selective force affecting the use of the roost site (Peters and Otis 2007) which will eventually change the number of individuals as well as the proportion using the Shrimp Farm 1 (Table 3).

\subsection{Daily number of individuals using the roost site in relation to the environmental factors}

A variety of variables associated with the change in the proportion in using the Shrimp Farm 1 and were species-specific (Table 3). Time of year influenced the 
use of the five species and conveys that roost use is related to the migration cycle of the species which matches with the work of Peters and Otis (2007). The birds significantly used more in the Spring. Area/length of water influenced the roost use of the Green Shanks and the Grey Plovers, whereas the proportion of the Green Shanks in the roost site correlated positively $(P<0.001)$ and the Grey Plovers correlated negatively $(P<0.01)$. Such result comes from each species' ecological behavior where Green Shanks used the lower part of the dyke in September 2011 when the area/length was relatively high however, Grey Plovers used the roost site in spite of how low the area/circumference ratio was, during the Spring and Fall, 2012. As in the case of the Terek Sandpiper, shorebirds consider disturbance as a factor when selecting roost sites. In this study however, the disturbance factor correlated with just Grey Plovers and Terek Sandpipers. This results from the discordance between the migration period and the time of harvesting, which prevented other species from being disturbed by harvesting. In the case of the Grey Plover, which used the roost even in the harvesting period, we could assume that more than a certain level of disturbance is needed to force the shorebirds away from the roost as in the case of Peters and Otis (2007). Grey Plovers used the roost in spite of the change in surface from harvesting, roosting in the edge of the harvesting points where the visual appearance had not changed. In high ambient temperatures, shorebirds could end up in a loss of energy (Rogers et al. 2006b). Instead of flying to a far distant roost and risking heat stress from flying (Rogers et al. 2006a, Rogers et al. 2006b, Peters and Otis 2007), Grey Plovers could have preferred the Shrimp Farm. As in the case of the temperature, wind speed could also be a factor when selecting the roost sites as "energy requirements will increase rapidly on windy days" (Evans, P. R. 1976). Dunlins (Handel and Gill 1992), Whimbrels (Peters and Otis 2007) and other species (Peters and Otis 2007) are already known to consider wind speed however, in our study the three species were not related to the wind speed.

\subsection{Conservation Implications}

The two Shrimp Farms are the major coastal inland roost sites currently in the southern Kanghwa Island and the shorebirds in Kanghwa Island roost on a dredged soil reclamation area, which is $10 \mathrm{~km}$ away in the Yeongjong
Island. A conservation plan is inevitable in this area and a construction of an artificial roosting site or a shorebird ecology-based management of the Shrimp Farm 1 should be considered.

Artificial roost sites should be based on scientific knowledge, including this study, of the shorebirds reflecting the species' ecology. However, Rogers et al. (2006a) insisted that "shorebirds make decisions based on thresholds rather than on probability algorithms that are much more information and computationally demanding." Therefore, although significant variables from this study are considered in the construction of an alternative roost site in the southern Kanghwa Island, the shorebirds might not prefer the newly constructed site to the traditional roost site as in the case of Zhijun Ma et al. (2004) resulting in a loss of biodiversity. Instead, there are literatures and a long time experience that shorebirds use traditional roost sites (Rehfisch et al. 2003 Zhijun Ma et al. 2004). So in shorebird conservation, better management in the Shrimp Farm 1 could be more effective than constructing a new roost site. And Kim (2003a) had described that the shorebirds have used the Shrimp Farm 1 which conveys that the shorebirds in the southern Kanghwa Island could have the site fidelity for a long period. Rogers et al. (2006a) mentioned that at nights shorebirds rely on memory to find a roost. Which further strengthens the idea that the shorebirds would prefer the Shrimp Farm 1 and as a result managing the traditional roost would be more effective. The suggesting management implication for the Shrimp Farm 1 is to regulate the area/length of water, control the farmwork time and eliminate the disturbance factors as in the result of this study (Table 2). In summer drought, opening the sluice valve in the range which the $S$. herbacea doesn't get inundated will help the shorebirds to thermoregulate (Rogers et al. 2006b) as well as provide a suitable area/circumference of flooded habitat. A little disturbance, farmers sowing seeds and thinning out once in a while, does not bother some shorebird species (Fig. 3). However, the result does not imply that the shorebirds will roost in spite of the farmers inside the Shrimp Farm. The farm work and providing shorebirds a roost site could be concurrently achieved when working time is slightly modified. Therefore, we propose the farmwork to be done before four hours to high tide, when the shorebirds start to look for the coastal inland roost sites (Kim 2003c), or work on a neap tide day when the high tide leaves the intertidal mudflat unflooded where the shorebirds could 
roost. And it would be better to move the agricultural machines placed in the dyke where Terek Sandpipers and Green Shanks usually use, to a place inside the bufferzone. Finding a resolution for the juxtaposition of shorebirds and men are vital and this research was in the middle of such circumstances. Therefore, we encourage others to refer to this study in protecting the shorebirds in the southern Kanghwa Island.

\section{Acknowledgements}

We thank H.J.Kim for the advice on the situation of the Kanghwa Island back in the year 2002. Several anonymous reviewers helped improve the manuscript. M.S.Kim, J.H.Choi, B.S.Ahn helped us in our field work and it couldn't have been possible if it were not for the members in the Lab of Animal Ecology at Kyung Hee University. We thank other senior scholars who have devoted their careers in studying shorebirds in Kanghwa Island, especially the lately deceased J.Y.Lee.

\section{References}

Burton, N. H., Evans, P. R., \& Robinson, M. A. (1996). Effects on shorebird numbers of disturbance, the loss of a roost site and its replacement by an artificial island at Hartlepool, Cleveland. Biological Conservation, 77(2), pp. 193-201.

Colwell, M. A., \& Dodd, S. L. (1997). Environmental and habitat correlates of pasture use by nonbreeding shorebirds, Condor, pp. 337-344.

Connor, E. F., \& McCoy, E. D. (1979). The statistics and biology of the species-area relationship. The American Naturalist, 113(6), pp. 791-833.

Crawley, M.J., (2013). The R Book. Second edition. John Wiley and Sons Ltd., West Sussex, England.

Danufsky, T., \& Colwell, M. A. (2003). Winter shorebird communities and tidal flat characteristics at Humboldt Bay, California. The Condor, 105(1), pp. 117-129.

Dekker, D. (1998). Over-ocean flocking by dunlins, Calidris alpina, and the effect of raptor predation at boundary bay, British Columbia. Canadian FieldNaturalist, 112(4), pp. 694-697.

Dekker, D., \& Ydenberg, R. (2004). Raptor predation on wintering dunlins in relation to the tidal cycle. The Condor, 106(2), pp. 415-419.

Evans, P. R. (1976). Energy balance and optimal foraging strategies in shorebirds: some implications for their distributions and movements in the non-breeding season. Ardea, 64(117), pp. 366.

Handel, C. M., \& Gill Jr, R. E. (1992). Roosting behavior of premigratory Dunlins (Calidris alpina). The Auk, pp. 57-72.

Kelsey, M. G., \& Hassall, M. (1989). Patch selection by Dunlin on a heterogeneous mudflat. Ornis Scandinavica, pp. 250-254.

Kim H. C. (2003a). Roosting habitats and movement of migrant shorebirds on Ganghwa and Yeongjong Island. Ph.D. dissertation, Kyung Hee University, Seoul, Republic of Korea pp. 43-61.

Kim H. C. (2003b). Roosting habitats and movement of migrant shorebirds on Ganghwa and Yeongjong Island. Ph.D. dissertation, Kyung Hee University, Seoul, Republic of Korea pp. 62-86.

Kim H. C. (2003c). Roosting habitats and movement of migrant shorebirds on Ganghwa and Yeongjong Island. Ph.D. dissertation, Kyung Hee University, Seoul, Republic of Korea pp. 24-42.

Kim H. C., \& Yoo, J. C. (2004). Local Movement of Shorebirds for Roosting between Ganghwa and Yeongjong Island in the West Coast of Korea. The Korean Journal of Ecology, pp. 27.

Korea Meteorological Administration. http:/www.kma.go.kr/ weather/observation/past_cal.jsp. Accessed in 10 April 2013

Lee K.S., Kim M.R., Lee S.W.,\& Lee H.S. (2004). The study for grading of the mudflat by birds, Journal of Wetlands Research, 6(1) pp. 105-115.

MacKinnon, J., Verkuil, Y. I., \& Murray, N. (2012a). IUCN situation analysis on East and Southeast Asian intertidal habitats, with particular reference to the Yellow Sea (including the Bohai Sea). Occasional Paper of the IUCN Species Survival Commission, 47, pp. 11-15.

MacKinnon, J., Verkuil, Y. I., \& Murray, N. (2012b). IUCN situation analysis on East and Southeast Asian intertidal habitats, with particular reference to the Yellow Sea (including the Bohai Sea). Occasional Paper of the IUCN Species Survival Commission, 47, pp. 7-8, 16-19.

MacKinnon, J., Verkuil, Y. I., \& Murray, N. (2012c). IUCN situation analysis on East and Southeast Asian intertidal habitats, with particular reference to the Yellow Sea (including the Bohai Sea). Occasional Paper of the IUCN Species Survival Commission, 47, 
pp. 4-5.

MacKinnon, J., Verkuil, Y. I., \& Murray, N. (2012d). IUCN situation analysis on East and Southeast Asian intertidal habitats, with particular reference to the Yellow Sea (including the Bohai Sea). Occasional Paper of the IUCN Species Survival Commission, 47, pp. 5-9.

MacKinnon, J., Verkuil, Y. I., \& Murray, N. (2012e). IUCN situation analysis on East and Southeast Asian intertidal habitats, with particular reference to the Yellow Sea (including the Bohai Sea). Occasional Paper of the IUCN Species Survival Commission, 47, pp. 69.

Moores, N. I. A. L. (2006). South Korea's shorebirds: a review of abundance, distribution, threats and conservation status. Stilt, 50, pp. 62-72.

Morrison, R. I. G., \& Hobson, K. A. (2004). Use of body stores in shorebirds after arrival on high-arctic breeding grounds. The Auk, 121(2), pp. 333-344.

Peters, K. A., \& Otis, D. L. (2007). Shorebird roost site selection at two temporal scales: is human disturbance a factor?. Journal of Applied Ecology, 44(1), pp. 196-209.

Pfister, C., Harrington, B. A., \& Lavine, M. (1992). The impact of human disturbance on shorebirds at a migration staging area. Biological Conservation, 60(2), pp. 115-126.

Piersma, T., Hoekstra, R., Dekinga, A., Koolhaas, A., Wolf, P., Battley, P., \& Wiersma, P. (1993). Scale and intensity of intertidal habitat use by knots Calidris canutus in the Western Wadden Sea in relation to food, friends and foes. Netherlands Journal of Sea Research, 31(4), pp. 331-357

$\mathrm{R}$ : A language and environment for statistical computing. (2012) R Foundation for Statistical Computing, Vienna,
Austria. ISBN 3-900051-07-0,

URL http://www.R-project.org/.

Rehfisch, M. M., Insley, H. U. G. H., \& Swann, B. (2003). Fidelity of overwintering shorebirds to roosts on the Moray Basin, Scotland: implications for predicting impacts of habitat loss. Ardea, 91(1), pp. 53-70.

Rhee, M. H., Park, H. J., \& Cho, J. Y. (2009). Salicornia herbacea: botanical, chemical and pharmacological review of halophyte marsh plant. J. Med. Plants Res, 3(8), pp. 548-555.

Rogers, D. I., Battley, P. F., Piersma, T., Van Gils, J. A., \& Rogers, K. G. (2006a). High-tide habitat choice: insights from modelling roost selection by shorebirds around a tropical bay. Animal Behaviour, 72(3), pp. 563-575.

Rogers, D. I., Piersma, T., \& Hassell, C. J. (2006b). Roost availability may constrain shorebird distribution: exploring the energetic costs of roosting and disturbance around a tropical bay. Biological Conservation, 133(2), pp. 225-235.

Skagen, S. K. (2006). Migration stopovers and the conservation of arctic-breeding calidridine sandpipers. The Auk, 123(2), pp. 313-322.

Stillman, R. A., Triplet, P., Aulert, C., Bouchet, A., Duhamel, S., Mayot, S., \& Goss-Custard, J. D. (2005). Modelling the efficacy of proposed mitigation areas for shorebirds: a case study on the Seine estuary, France. Biological Conservation, 123(1), pp. 67-77.

논문접수일 : 2013년 04월 12일 심사의뢰일 : 2013년 04월 12일 심사완료일 : 2013년 05월 22일 
Appendix. Environmental variables measured during the 26 surveys on the southern Kanghwa Island, South Korea. The Temperature and the Wind Speed is calculated as mean of the values $(\mathrm{N}=13)$ from two hours to high tide. And the species total population and the number of individuals using the Shrimp Farm 1 and Shrimp Farm 2, respectively inside the parentheses, are presented.

Survey Time

Sep_1_2011 Sep_2_2011 Oct_1_2011 Oct_2_2011 Nov_1_2011 Nov_2_2011 Dec_2011 Jan_2012 Feb_2012

\begin{tabular}{|c|c|c|c|c|c|c|c|c|c|}
\hline \multicolumn{10}{|l|}{ Environmental variables } \\
\hline $\begin{array}{l}\text { Area/Length of } \\
\text { Water }\end{array}$ & 2166 & 735 & 398 & 247 & 162 & 107 & 110 & 113 & 115 \\
\hline Disturbance & 0 & 0 & 0 & 0 & 0 & 0 & 0 & 0 & 0 \\
\hline Temperature $\left({ }^{\circ} \mathrm{C}\right)$ & 24.6 & 26.1 & 20.0 & 13.0 & 17.2 & 8.9 & -3.2 & 4.0 & 4.8 \\
\hline (SD) & $(0.6)$ & $(0.9)$ & $(0.7)$ & $(0.3)$ & $(0.5)$ & $(0.3)$ & $(0.2)$ & $(0.2)$ & $(0.3)$ \\
\hline Wind Speed $(\mathrm{m} / \mathrm{s})$ & 1.5 & 3.8 & 2.2 & 6.6 & 1.9 & 3.8 & 6.6 & 4.0 & 2.0 \\
\hline (SD) & $(0.7)$ & $(0.8)$ & $(1.0)$ & $(0.8)$ & $(0.8)$ & $(0.6)$ & $(0.9)$ & $(0.8)$ & $(0.5)$ \\
\hline Area of Water $\left(\mathrm{m}^{2}\right)$ & 179767 & 159975 & 140183 & 120391 & 100599 & 80809 & 95444 & 110076 & 124708 \\
\hline Length of Water(m) & 83 & 217.8 & 352.6 & 487.4 & 622.2 & 757 & 865.5 & 974 & 1082.5 \\
\hline \multicolumn{10}{|l|}{ Species } \\
\hline Eastern Curlew & $643(72,0)$ & $147(147,0)$ & $1584(0,0)$ & $755(0,0)$ & $36(0,0)$ & 0 & 0 & 0 & 0 \\
\hline Green Shank & $394(295,0)$ & $462(259,0)$ & $276(25,0)$ & $264(31,0)$ & $38(0,38)$ & $11(0,11)$ & 0 & 0 & 0 \\
\hline Bar-tailed Godwit & $1(0,0)$ & $114(112,0)$ & $1(0,0)$ & $5(0,0)$ & 0 & 0 & 0 & 0 & 0 \\
\hline Great Knot & $8(8,0)$ & $9(9,0)$ & $121(0,0)$ & $3(0,0)$ & 0 & 0 & 0 & 0 & 0 \\
\hline Grey Plover & $8(5,0)$ & 0 & $109(0,0)$ & $21(0,0)$ & $30(0,0)$ & $5(0,0)$ & 0 & $2(0,0)$ & $32(0,0)$ \\
\hline Dunlin & 0 & 0 & 0 & $487(0,0)$ & $2(0,0)$ & 0 & $16(0,0)$ & 0 & $82(0,0)$ \\
\hline Whimbrel & $18(10,0)$ & $15(0,0)$ & 0 & 0 & 0 & 0 & 0 & 0 & 0 \\
\hline Black-tailed Godwit & $76(75,0)$ & $20(20,0)$ & $190(190,0)$ & 0 & 0 & 0 & 0 & 0 & 0 \\
\hline Terek Sandpiper & $77(47,0)$ & $58(0,0)$ & $16(0,0)$ & $5(0,0)$ & 0 & 0 & 0 & 0 & 0 \\
\hline Red-necked Stint & 0 & 0 & 0 & 0 & 0 & 0 & 0 & 0 & 0 \\
\hline Eurasian Curlew & $14(2,0)$ & 0 & $21(0,0)$ & $250(0,0)$ & $192(0,0)$ & 0 & $76(0,0)$ & 0 & 0 \\
\hline $\begin{array}{l}\text { Eurasian } \\
\text { Oystercatcher }\end{array}$ & $3(0,0)$ & 0 & $44(0,0)$ & $22(0,0)$ & $64(0,0)$ & 0 & 0 & 0 & $11(0,0)$ \\
\hline Wood Sandpiper & 0 & 0 & 0 & 0 & 0 & 0 & 0 & 0 & 0 \\
\hline
\end{tabular}




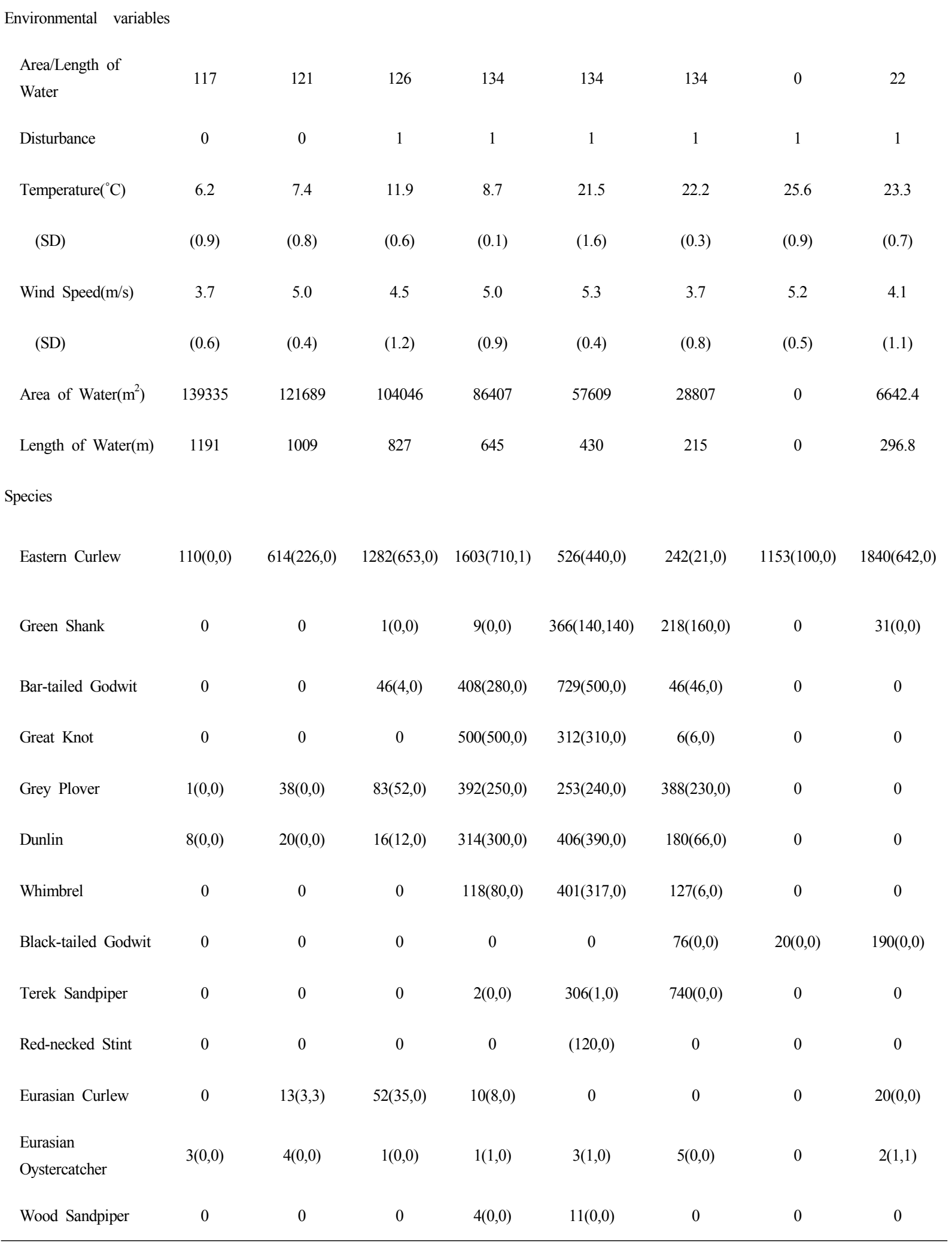




\begin{tabular}{|c|c|c|c|c|c|c|c|c|c|}
\hline \multicolumn{10}{|l|}{ Environmental variables } \\
\hline $\begin{array}{l}\text { Area/Length of } \\
\text { Water }\end{array}$ & 22 & 22 & 22 & 22 & 19 & 13 & 18 & 26 & 31 \\
\hline Disturbance & 1 & 1 & 1 & 1 & 1 & 2 & 2 & 2 & 2 \\
\hline Temperature $\left({ }^{\circ} \mathrm{C}\right)$ & 25.3 & 31.6 & 27.9 & 26.5 & 21.5 & 21.2 & 16.4 & 9.6 & 4.8 \\
\hline (SD) & $(0.2)$ & $(1.2)$ & $(0.4)$ & $(0.7)$ & $(0.2)$ & $(0.4)$ & $(0.4)$ & $(0.2)$ & 0.4 \\
\hline Wind Speed(m/s) & 1.9 & 2.8 & 2.7 & 4.0 & 3.2 & 4.3 & 5.7 & 6.3 & 2.7 \\
\hline (SD) & $(0.9)$ & $(0.5)$ & $(0.3)$ & $(1.0)$ & $(0.7)$ & $(0.6)$ & $(0.9)$ & $(0.8)$ & 0.8 \\
\hline Area of Water $\left(\mathrm{m}^{2}\right)$ & 13284.6 & 19926.8 & 26569 & 33211 & 22782 & 12353 & 4731 & 9576 & 14421 \\
\hline Length of Water(m) & 593.6 & 890.4 & 1187.2 & 1484 & 1205.5 & 927 & 267 & 365 & 463 \\
\hline \multicolumn{10}{|l|}{ Species } \\
\hline Eastern Curlew & $2455(530,0)$ & $735(0,0)$ & $1733(0,0)$ & $1498(2,0)$ & $1426(51,30)$ & $190(0,0)$ & $55(0,0)$ & 0 & 0 \\
\hline Green Shank & $35(0,31)$ & $286(0,0)$ & $664(0,262)$ & $411(0,411)$ & $512(2,160)$ & $175(0,0)$ & $27(0,23)$ & 0 & 0 \\
\hline Bar-tailed Godwit & $192(88,0)$ & $38(0,0)$ & $492(0,0)$ & $56(0,0)$ & $16(0,0)$ & $11(0,0)$ & $6(0,0)$ & 0 & 0 \\
\hline Great Knot & 0 & 0 & 0 & $20(0,20)$ & $1(0,0)$ & 0 & 0 & 0 & 0 \\
\hline Grey Plover & $7(0,0)$ & $95(16,0)$ & $195(0,0)$ & $152(0,0)$ & $88(3,8)$ & $48(2,0)$ & $16(0,0)$ & 0 & 0 \\
\hline Dunlin & 0 & 0 & 0 & $1(0,0)$ & $33(0,0)$ & $251(0,0)$ & $34(0,0)$ & 0 & 0 \\
\hline Whimbrel & $8(2,0)$ & $156(0,0)$ & $115(0,0)$ & $128(0,2)$ & $39(0,0)$ & $2(0,0)$ & 0 & 0 & 0 \\
\hline Black-tailed Godwit & $1(0,0)$ & 0 & 0 & 0 & 0 & $18(0,0)$ & 0 & 0 & 0 \\
\hline Terek Sandpiper & $543(0,0)$ & $312(0,0)$ & $589(0,135)$ & $391(0,0)$ & $271(0,0)$ & $104(0,0)$ & 0 & 0 & 0 \\
\hline Red-necked Stint & 0 & 0 & 0 & 0 & 0 & 0 & 0 & 0 & 0 \\
\hline Eurasian Curlew & $1(1,0)$ & $55(0,0)$ & $29(0,0)$ & $5(0,0)$ & $24(0,0)$ & $654(0,0)$ & $668(0,0)$ & 0 & 0 \\
\hline $\begin{array}{l}\text { Eurasian } \\
\text { Oystercatcher }\end{array}$ & $3(0,0)$ & 0 & $35(0,0)$ & $22(0,0)$ & $21(0,0)$ & $26(0,0)$ & $5(0,0)$ & 0 & 0 \\
\hline Wood Sandpiper & 0 & 0 & 0 & $1(1,0)$ & $5(0,0)$ & 0 & $7(0,0)$ & 0 & 0 \\
\hline
\end{tabular}

